\title{
You can't judge a book by its cover: evolving professional responsibilities, liabilities and 'judgecraft' when a party has Asperger's Syndrome
}

\author{
PenNy CoOper ${ }^{1}$
}

University of London and 39 Essex Chambers

and

Clare Allely2,3

University of Salford and Gothenburg University

\begin{abstract}
In the context of increasing legal emphasis on fairness for people with disability, this article analyses the responsibilities and liabilities of lawyers in relation to the recognition and identification of client disability, and specifically Asperger's Syndrome, prior to a hearing. This article also analyses the judge's responsibilities when a party has Asperger's Syndrome. Lord Justice Gillen's seven points of principle and practical guidance for fair hearings when a party has a disability (Galo v Bombardier Aerospace UK) ${ }^{4}$ are used as a framework to explore the art of judging, or 'judgecraft'.
\end{abstract}

But always in the attic of my mind I dreamed of a magical machine that would soothe me and make me less different. ${ }^{5}$

\section{Introduction}

7 he formal identification of what is termed 'Asperger's Syndrome' occurred less than 80 1 years ago; 'Kanner's classic paper (1943) outlined the behaviour pattern, present from early in life, which he named "early infantile autism".'6 Accounts already existed 'of individual children whose behaviour fitted the picture Kanner later described' but Kanner was the first to publish a description of a series of such cases. ${ }^{7}$ Asperger's Syndrome is named after the scientist who, a year after Kanner's paper, published his own about a group of autistic children who were in the normal range of intelligence. ${ }^{8}$ As noted in case law,

1 Barrister, Senior Research Fellow (Birkbeck, University of London) and Professor of Law (City University of London (Hon)), Academic Associate, 39 Essex Chambers, Chair and Co-founder of The Advocate's Gateway.

2 Lecturer in Psychology, School of Health Sciences, University of Salford, Manchester, England, and affiliate member of the Gillberg Neuropsychiatry Centre, Sahlgrenska Academy, University of Gothenburg, Gothenburg, Sweden.

3 The authors thank the editor and the reviewers for their comments on an earlier draft as well as Felicity Gerry QC for her suggestions on an early draft. The usual caveat applies.

4 [2016] NICA 25.

5 T Grandin, Emergence - Labelled Autistic (Grand Central 1996) 69.

6 L Wing, 'The Definition and Prevalence of Autism: A Review' (April 1993) 2(2) European Child and Adolescent Psychiatry 61-74 (Hogrete \& Huber).

7 Ibid citing L Kanner, 'Autistic Disturbances of Affective Contact' (1943) 2 Nervous Child 217-50.

8 H Asperger, 'Die autistischen Psychopathen im Kindesalter' (1944) 17 Archiv für Psychiatric und Nervenkrankheiten 76-136. 
Asperger's Syndrome was first named in the International Classification of Diseases (ICD$10)^{9}$ in $1990 .{ }^{10}$

Though there is wide agreement that Asperger's Syndrome is an autism spectrum condition, there is debate as to whether it should exist as a separate diagnostic label. The fifth edition of the Diagnostic and Statistical Manual of Mental Disorders (DSM-V, which replaced DSM-IV in May 2013) removed Asperger's Syndrome as a separate disorder and states:

Individuals with a well-established DSM-IV diagnosis of autistic disorder, Asperger's disorder, or pervasive developmental disorder not otherwise specified should be given the diagnosis of autism spectrum disorder. ${ }^{11}$

The definition of Autism Spectrum Disorder (ASD) in DSM-V includes:

Persistent deficits in social communication and social interaction across multiple contexts, for example: 1 . Deficits in social-emotional reciprocity, ranging, for example, from abnormal social approach and failure of normal back-and-forth conversation . . . Deficits in developing, maintaining, and understanding relationships, ranging, for example, from difficulties adjusting behaviour to suit various social contexts ...

The DSM-V includes the new name of Autism Spectrum Disorder to encompass four previously separate disorders, namely autistic disorder (autism), Asperger's Syndrome disorder, childhood disintegrative disorder and pervasive developmental disorder not otherwise specified. However, the ICD-10 retains the diagnostic code of Asperger's Syndrome. ${ }^{12}$ It is possible that the next edition of the ICD (ICD-11) will align the revisions made to the diagnostic criteria for autism spectrum disorders in the DSM-V.

The term Asperger's Syndrome is sometimes used interchangeably with 'HighFunctioning Autism Spectrum Condition', the latter being a term used to describe a person with autism with at least average IQ. Asperger's Syndrome is an autism spectrum condition (ASC). Hereinafter we will use ASC when we are referring collectively to the range of autism conditions on the spectrum. ASC gives rise to 'a disability in social and communication development, alongside unusually narrow interests ("obsessions") and repetitive behaviour'. ${ }^{13}$ There is no medical treatment available to cure the basic impairments associated with ASC. The prevalence of ASC in England is approximately 10 per 1000 , though it is more commonly found in males, and adults have enduring problems with communication and social understanding. ${ }^{14}$

9 Published by the World Health Organization.

10 R v Reynolds [2004] EWCA Crim 1834, [8].

11 DSM-V. A copy of the diagnostic criteria for ASD 299.00 (F84.0) is available at $<$ www.autismspeaks.org/what-autism/diagnosis/dsm-5-diagnostic-criteria>.

122016 ICD-10-CM Diagnosis Code F84.5.

13 B Chakrabarti and S Baron-Cohen, 'Understanding the Genetics of Empathy and the Autistic Spectrum' in S Baron-Cohen, H Tager-Flusberg and M Lombardo (eds), Understanding Other Minds (3rd edn, Oxford University Press 2013) 327.

14 T Brugha, S McManus, J Bankart, F Scott, S Purdon, J Smith, P Bebbington, R Jenkins and H Meltzer, 'Epidemiology of Autism Spectrum Disorders in Adults in the Community in England' (2011) 68(5) Archives of General Psychiatry 459-65. 


\section{The Autism Act (Northern Ireland) 2011 and understanding of ASC in the general public of Northern Ireland}

The Autism Act (Northern Ireland) 2011 amended $^{15}$ the Disability Discrimination Act 1995 (DDA) and removed any doubt that ASCs fall within the definition of disability. Using a large-scale general population survey $(\mathrm{N}=1204)$, Dillenburger and colleagues (2013) investigated autism awareness, knowledge about autism and perceptions about autism interventions in Northern Ireland. Findings revealed high levels of autism awareness. More than 80 per cent of the sample were aware of ASC. Additionally, more than 60 per cent of these respondents knew someone with ASC either in their own family, circle of friends or work colleagues. Overall, respondents demonstrated relatively accurate knowledge of both the difficulties and strengths faced by individuals with ASC. However, the respondents' perceptions of interventions and service-provider responsibilities were 'vague and uncertain'. ${ }^{16}$

In another study based on 500 people from the Northern Irish general public (aged 16 and over), Stewart (2008) investigated what they knew about autism. Stewart's study found that the majority of people had heard of autism ( 87 per cent) and, of these, 79 per cent were aware about some of the key aspects of autism. However, of the 500 people in the study only 48 per cent had heard of Asperger's Syndrome. Moreover, many respondents had misconceptions about autism. For example, 'thinking that individuals with autism swear inappropriately $(48 \%)$, were intentionally rude $(24 \%)$, unable to walk $(11 \%)$, are mostly children (55\%), or had special abilities $(62 \%)^{\prime} \cdot{ }^{17}$

\section{The Galo case and procedural (un)fairness}

The Court of Appeal decision in the case of Galo $v$ Bombardier Aerospace $U K^{18}$ has placed a spotlight on procedural fairness when a party to legal proceedings has a disability. Mr Galo has Asperger's Syndrome. He appealed the decision of the Industrial Tribunal ${ }^{19}$ which dismissed his claim against his previous employers. In summary, Mr Galo was suspended from work for alleged gross misconduct, namely throwing 'an item of work equipment behind him' and shouting at an occupational health doctor examining him. MrGalo launched a grievance against his employers alleging victimisation and discrimination; his employers investigated and dismissed his grievance and, after a disciplinary investigation and hearing, terminated his employment for gross misconduct. He made a claim in the industrial tribunal for, amongst other things, unfair dismissal and disability discrimination.

Prior to Mr Galo launching his claim, his employers obtained a medical report from a clinical psychologist, Dr Lusty, which noted an earlier educational psychologist report concluding Mr Galo had Asperger's Syndrome and Dr Lusty herself agreed with this diagnosis. The most curious thing about the way the case was managed in the Industrial Tribunal is that 'no attempt appears to have been made to engage with or address his

15 Art 1(1) states: 'The Disability Discrimination Act 1995 is amended in its application to Northern Ireland as follows. (2) At the end of paragraph 4(1) of Schedule 1 insert- "(i) taking part in normal social interaction; or (j) forming social relationships".

16 K Dillenburger, J A Jordan, L McKerr, P Devine and M Keenan, 'Awareness and Knowledge of Autism and Autism Interventions: A General Population Survey' (2013) 7(12) Research in Autism Spectrum Disorders 1558-67.

17 S Stewart, I Exist: The Message from Adults with Autism in Northern Ireland (The National Autistic Society 2008).

18 [2016] NICA 25.

19 Patrick Galo v Bombardier Aerospace Case Refs: 751/13 [2014] IT700/14. 
disability of [Asperger's Syndrome]'. ${ }^{20}$ Despite the claimant furnishing the court and the parties with medical evidence that he was mentally unwell (in addition to having Asperger's Syndrome) and thus unable to comply with case management directions and unfit to attend on the date of the final hearing, the tribunal dismissed his claim in his absence. The Court of Appeal allowed the appeal, finding that Mr Galo had not benefited from fair case management or a fair final hearing and referred his case 'back for a hearing before a differently constituted Tribunal who will doubtless take the steps outlined in this judgment'. ${ }^{21}$

Giving judgment in the Court of Appeal, Gillen LJ noted that '[f]or many years now the courts in Northern Ireland have recognised the particular need to ensure fairness in hearings where one or more parties suffers from a disability'22 and set out in six bullet points (expanded below by the authors) that there is an increased emphasis on fairness arising out of the following. ${ }^{23}$

- The Human Rights Act 1998 including Article 6 of the European Convention on Human Rights (ECHR), involving the right to a fair hearing, and Article 14 of the ECHR, placing a positive obligation on states to ensure there is a benefit from anti-discrimination.

- The European Union Directive 2000/78/EC of 27 November 2000 establishing a general framework for equal treatment in employment and occupation with particular reference to Article 9(1).

- The UN Convention on the Rights of Persons with Disabilities which reads at Article 13:

1 States Parties shall ensure effective access to justice for persons with disabilities on an equal basis with others, including through the provision of procedural and age appropriate accommodation, in order to facilitate their effective role as direct and indirect participants, including as witnesses, in all legal proceedings, including at investigative and other preliminary stages.

2 In order to help to ensure effective access to justice for persons with disabilities, States Parties shall promote appropriate training for those working in the field of administration of justice . . .

- The DDA and the application of the judicial acts exclusion - this legislation protects from discrimination those who have a 'disability' as defined by the Act and places duties on employers and public service providers to make 'reasonable adjustments'. However, the general duty imposed by the DDA on public bodies ${ }^{24}$ does not extend to 'a judicial act (whether done by a court, tribunal or other person)' or 'an act done on the instructions, or on behalf,

20 Ibid [23].

21 Ibid [66].

22 Ibid [52].

23 Galo v Bombardier Aerospace UK (n 4). Although Galo was about an employment law dispute and therefore the judgment describes in these six bullet points the legal context relevant to the facts, there is an even wider context of law which also provides emphasis on ensuring fairness in proceedings: see, for example, the 'special measures' in the Criminal Evidence (Northern Ireland) Order 1999; the European Union Directive 2012/29/EU of 25 October 2012, which establishes minimum standards on the rights, support and protection of victims of crime; and Art 12 of the UN Convention on the Rights of the Child 1990. 
of a person acting in a judicial capacity'. 25 Whilst the 'judicial function' is exempt from the prohibition on discrimination in the exercise of public functions, this exemption is likely to be limited to the core, adjudicative and listing functions. ${ }^{26}$

- The European Union Charter on Fundamental Rights. ${ }^{27}$ The Charter sets out fundamental rights and freedoms. It became legally binding when the Treaty of Lisbon entered into force on 1 December 2009. The Charter declares '[e]veryone is equal before the law'. Article 21 prohibits: '[a]ny discrimination based on any ground such as sex, race, colour, ethnic or social origin, genetic features, language, religion or belief, political or any other opinion, membership of a national minority, property, birth, disability, age or sexual orientation'. Article 26 states: '[t]he Union recognises and respects the right of persons with disabilities to benefit from measures designed to ensure their independence, social and occupational integration and participation in the life of the community'.

- The Equality Act 2010 - the Equality Act 2010 replaced the DDA in England and Wales. The Equality Commission for Northern Ireland has stated that ' $[\mathrm{t}]$ he need for reform of the equality legislation in Northern Ireland has been heightened by developments in Great Britain'. ${ }^{28}$

In Galo, Gillen LJ set out seven considerations, a mix of principles and guidelines, ${ }^{29}$ for procedural fairness at hearings when a party has a disability:

(1) the entitlement to a fair hearing including to participate effectively;

(2) the impact of the mental health disability on the litigant;

(3) the Equal Treatment Bench Book (ETBB);

(4) how a person with a particular disability might present;

(5) the benefit of a McKenzie Friend/an independent mental health advocate;

(6) a modified approach, if necessary, to obtaining evidence; and

(7) an early 'ground rules hearing';

These seven points will be considered in detail below from page 45 onwards. Unless a court is aware of a party's disability, it is obviously not in a position to take it into account. Thus, before considering the art of judging, or 'judgecraft', under these seven headings, we first consider what, if any, responsibility a lawyer has to recognise and respond to disability in a client facing a court hearing and, specifically, to recognise the "hidden disability' that is Asperger's Syndrome.

25 DDA, s 49C.

26 Judicial College, Equal Treatment Bench Book (Judicial College 2013) 1. See Engel v Joint Committee for Parking and Traffic Regulation outside London (PATROL) [2013] ICR 1086; [2013] IRLR 787 and J W Rackham $v$ NHS Professionals Ltd [2015] UKEAT 0110_15_1612 where the Employment Appeals Tribunal said: '[w]e do not think it could sensibly be disputed that a Tribunal has a duty as an organ of the state, as a public body, to make reasonable adjustments to accommodate the disabilities of Claimants'.

27 European Union, Charter of Fundamental Rights of the European Union, 26 October 2012, 2012/C 326/02 $<$ www.refworld.org/docid/3ae6b3b70.html>.

28 See Equality Commission for Northern Ireland, 'Gaps in Equality Law between Great Britain and Northern Ireland' (March 2014) < www.equalityni.org/ECNI/media/ECNI/Consultation\%20Responses/2014/Gapsin-Equality-Law-in-GB-and-NI-March-2014.pdf>.

29 Ibid [53]. 


\section{A lawyer's responsibility to identify a client's disability}

There is no explicit legal obligation on a lawyer to diagnose their client's disability (if any), nor is it suggested that there should be; lawyers are not medical practitioners qualified to diagnose physical and mental conditions. It is not part of the lawyer's role to make a medical diagnosis just as it was not part of the police's role to diagnose autism in the case of $\mathrm{ZH} v$ The Commissioner of Police for the Metropolis. ${ }^{30}$

In $\mathrm{ZH}$ the police responded to a call to attend a public swimming pool where an autistic and epileptic boy $(\mathrm{ZH})$ was 'stuck' in the swimming pool. $\mathrm{ZH}$ (by his litigation friend) successfully sued the police for their use of restraint and detention techniques which were found by the court to be in breach of the DDA ${ }^{31}$ which made it unlawful for a public authority to discriminate against a disabled person in carrying out its public functions. $\mathrm{ZH}$ was awarded damages for assault and false imprisonment and, under the Human Rights Act 1998, for breach of Article 3 of the ECHR: 'No one shall be subjected to torture or to inhuman or degrading treatment or punishment.' The police authority appealed and lost. Delivering judgment in the Court of Appeal, the Master of the Rolls said:

I accept that police officers are not required to make medical diagnoses. They are not doctors. But the important feature of the present case is that, even before they restrained $\mathrm{ZH}$, they knew that he was autistic and epileptic. They knew (or ought to have known) that autistic persons are vulnerable and have limited understanding. 32

The general principle at the heart of the $Z H$ case is that a professional's actions carried out in pursuance of the responsibilities of their role will be judged by what they knew or ought to have known at the time.

Just as it is a judge's professional responsibility to promote the proper administration of justice, ${ }^{33}$ lawyers also have a professional responsibility to promote the proper administration of justice: a barrister has 'an over-riding duty to the court to ensure the proper administration of justice'; 34 and a solicitor 'shall never forget that they should put first not their right to compensation for their services, but the interests of their clients and the exigencies of the administration of justice'. ${ }^{35}$ One aspect of the proper administration of justice is:

... the necessity to remove barriers to inclusion that create disadvantage and discrimination. To that extent, courts must take all steps possible to ensure that people with a learning disability are able to actively participate in decisions affecting their lives. They must be supported in ways that take account of their individual needs and to help them to be as independent as possible. ${ }^{36}$

This obligation to remove barriers undoubtedly applies to all forms of disability, not just learning disability, which might impair effective participation. Thus it is submitted that if

30 [2013] EWCA Civ 69.

31 The DDA applied at the time of the events, but it has since been repealed in England and Wales and replaced by the Equality Act 2010.

32 ZH v The Commissioner of Police for the Metropolis [2013] EWCA Civ 69, [66]-[67].

33 For example, Judicial College (n 25) ch 2, citing the judicial oath: 'I will do right to all manner of people after the laws and usages of this realm, without fear or favour, affection or ill will.'

34 Bar Council, Code of Conduct for the Bar of Northern Ireland (Bar Council 2016) 8, para 4.1.

35 The Law Society of Northern Ireland, The Solicitors Practice Regulations 1987 (as amended) (Law Society 2013) para 17.

36 Gillen $\mathrm{J}$ in $\operatorname{Re} G$ and $A$ [2006] NIFam 8 [5(2)]. 
a lawyer knows their client has a disability and that disability is likely to create a barrier to their effective participation at a hearing, the lawyer, with their client's informed consent, should disclose this to the court so that adjustments may be made and justice may be administered properly. It is the lawyer's duty not only to their client but also to the proper administration of justice.

However, if a lawyer does not know that their client has a disability, it is less clear when it can be said that they ought to know. It might be argued that lawyers have no responsibility in this regard in the absence of being told expressly by a client that they have a disability. However, this would be an unattractive argument and unworkable in practice since there are numerous reasons why a client might not disclose a disability to their lawyer: they might not know they have a disability; they might have been told by others they have a disability but they consider that they do not have a disability; 37 they might feel embarrassed that they have a disability; they might fear that a disability will count against them and so on. For these reasons the responsibility cannot rest solely with a client to inform their lawyer of their disability.

In the absence of a client revealing to the lawyer that they have a disability, and in the absence of a clear outward physical sign, it might be argued that it is unreasonable to say a lawyer ought to know; in general, psychological vulnerability often goes unidentified. In 2010 Gudjonsson wrote about the identification of psychological vulnerability in suspects at the police station:

$\ldots$ in the majority of cases vulnerabilities [of witnesses and suspects who are interviewed at police stations] are not identified, and even if identified, this information is not always acted upon in terms of service provisions. This problem needs to be urgently addressed and some reliable form of screening needs to be developed, implemented, and acted upon. ${ }^{38}$

Research in Northern Ireland by Bunting et al, looking at the criminal justice system, reached similar conclusions:

Vulnerable witnesses, especially adults with learning disabilities, mental health problems etc. are not always being identified early enough in the process. Ideally this identification would be made by the PSNI [Police Service of Northern Ireland] on first contact with victims and witnesses; however this does not always happen; vulnerable adults may not be identified at all or only identified late in the process. ${ }^{39}$

In 2015 a joint inspectorate report was published after a review of Crown Prosecution Service (CPS) files in England and Wales. The report noted with concern that in 41 of the 195 case files (21 percent) where vulnerable victims and witnesses were involved, the police did not identify their vulnerability and did not manage the associated risk through the court process. There were 5 cases where the CPS neither identified nor managed the risk. ${ }^{40}$

The rates of diagnosis of ASC have increased since 1980, which raises the issue of whether some children who previously had other diagnoses are now being diagnosed with autism. A number of studies have found evidence to support this. For instance, in their

37 For example, some people prefer the term 'difference' rather than 'disability'.

38 G Gudjonsson, 'Psychological Vulnerabilities during Police Interviews. Why are They important?’ (2010) 15 Legal and Criminological Psychology 161-75, 170.

39 Lisa Bunting, David Hayes and Gillian Clifford, Special Measures for Vulnerable Witnesses in Northern Ireland (Department of Justice (DOJ) 2013) 3-4.

40 Her Majesty's Inspectorate of Constabulary (2015), Witness for the Prosecution: Identifying Victim and Witness Vulnerability in Criminal Case Files, 10. Report available at <www.justiceinspectorates.gov.uk/hmic/wpcontent/uploads/vulnerability-in-criminal-case-files.pdf >. 
study based on 38 adults, Bishop, Whitehouse, Watt and Line ${ }^{41}$ found that the majority of adults with ASC had previously been diagnosed with pragmatic language impairments during their childhood. Therefore, some children who today would fulfil the diagnostic criteria for ASC would have received alternative diagnoses in the past in childhood, such as developmental language disorders.

A study based on a small sample of professionals in, or associated with, the criminal justice system suggests that practitioners would like more training to determine what special adjustments may be needed for those with communication needs. The study also concluded that guidance ${ }^{42}$ for advocates on identifying vulnerability does not appear to be reflected in practice. ${ }^{43}$

Another survey of a small number of legal practitioners and members of the autism community suggested that:

... the variation in legal practitioners' experience of [ASC] is dependent on a number of factors: 1) personal experience of the condition; 2) having conducted their own research or being 'self-taught' in the area of [ASC]; 3) previous experience of dealing with or representing [ASC] individuals; and 4) training - of which there was a lack of and a strong demand for by all groups. ${ }^{44}$

Findings from research, far from being a reason to set the bar very low for lawyers, emphasise the need for lawyers to become adept at asking appropriate questions and at identifying signs of possible psychological disability in their clients.

Whether a lawyer ought to know of a client's disability will be fact-specific and will depend on whether or not there are indicators. Lawyers need to be aware of indicators of disability, always keep the possibility of client vulnerability under review, ${ }^{45}$ and proactively seek information from the client. Advice is available online from The Advocate's Gateway, a website providing free access to practical, evidence-based guidance on vulnerable witnesses and defendants in the form of toolkits. Toolkit 10 on The Advocate's Gateway 46 includes a list of questions that could be asked which 'are more likely to elicit useful and reliable information compared to questions such as "Do you have a learning disability?" or "Are you disabled?" 47 Where a disability is suspected, the lawyer's role is not to diagnose but to refer the client for diagnostic assessment. If the suspected disability or condition is an ASC such as Asperger's Syndrome, one leading expert advises that the 'diagnostic assessment for Asperger's [S] yndrome' needs 'to include an evaluation of the person's ability to understand and express emotions, not only

41 D V Bishop, A J Whitehouse, J H Watt, and E A Line, 'Autism and Diagnostic Substitution: Evidence from a Study of Adults with a History of Developmental Language Disorder' (2008) 50(5) Developmental Medicine and Child Neurology 341-5.

42 P Cooper, Toolkit 10 Identifying Vulnerability in Witnesses and Defendants (Inns of Court College of Advocay 2017) $<$ www.theadvocatesgateway.org/images/toolkits/10-identifying-vulnerability-in-witnesses-and-parties-andmaking-adjustments-2017.pdf>.

43 R Ewin, 'The Vulnerable and Intimidated Witness: A Study of the Special Measure Practitioner' (2016) 2(1) Journal of Applied Psychology and Social Science 12-40.

44 K Maras, L Crane, S Mulcahy, T Hawken, P Cooper, D Wurtzel and A Memon, 'Brief Report: Autism in the Courtroom: Experiences of Legal Professionals and the Autism Community' (in press).

45 Just as the tribunal must keep its adjustments 'under review': Galo v Bombardier Aerospace UK (n 4) [53(7)].

46 The Advocate's Gateway is hosted by the the Inns of Court College of Advocacy (ICCA, formerly the ATC). See <www.theadvocatesgateway.org $>$. The website's guidance has been widely endorsed by the senior judiciary both in England and Wales and in Northern Ireland, for example, see R v Lubemba [2014] EWCA Crim 2064 and The Right Honourable Lord Justice Gillen/The Review Group, Review of Civil and Family Justice: The Review Group's Draft Report on Civil Justice (JSB 2016) 199, para 14.75.

47 Cooper (n 42) 2.2. 
to confirm the diagnosis, but also to screen for the possibility of an additional mood disorder, especially anxiety or depression'. ${ }^{48}$

\section{Identifying Asperger's Syndrome in a client}

Asperger's Syndrome is not necessarily obvious because '[y] ou cannot tell that someone has Asperger's Syndrome by looking at them. Because of this Asperger's Syndrome is sometimes called a hidden disability.' 49 There has been no research to date which has empirically investigated the effectiveness or utility of screening defendants or witnesses for ASC including Asperger's Syndrome. According to the National Autistic Society, autism 'is much more common than many people think. There are around 700,000 [children and adults] in the UK living with autism. 50

Appellate criminal case law ${ }^{51}$ provides examples of defendants who have been on trial and convicted, only subsequently to be diagnosed with Asperger's Syndrome: $\mathrm{R} v$ Reynolds $5^{2}$ [2004]; R v Sultan ${ }^{53}$ [2008]; and R v Thompson ${ }^{54}$ [2014]. Suspects have been diagnosed after arrest, ${ }^{55}$ albeit sometimes several years after arrest. Gary McKinnon fought his extradition to the USA where the authorities sought to try him for gaining unauthorised access to 97 government computers between 1 February 2001 and 19 March 2002. He was officially diagnosed with Asperger's Syndrome on 23 August 2008 having been first arrested on 19 March 2002 by the Hi-Tech Crime Unit: 56 'On 16 October 2012, the Home Secretary decided not to extradite Mr McKinnon to the US on the basis of his health. 57

In $R v$ Hayes, ${ }^{58}$ Tom Hayes was diagnosed with Asperger's Syndrome on 28 April 2015, less than one month before his trial began ${ }^{59}$ and over three years after he had first been arrested. Mr Hayes' diagnosis may not have come as a surprise to those who knew him or to his former work colleagues, some of whom nicknamed him 'Rain Man'60 - after the 1988 film starring Dustin Hoffman, who played Raymond, an autistic savant - and 'Kid Asperger's'. ${ }^{61}$

48 T Attwood, The Complete Guide to Asperger's Syndrome (Jessica Kingsley 2007) 128.

49 National Autistic Society, Easy-read: What is Asperger's Syndrome? <www.autism.org.uk/about/whatis/asperger.aspx>.

50 From The National Autistic Society website, 'Autism Facts and History' <www.autism.org.uk/about/whatis/myths-facts-stats.aspx > which cites the NHS Information Centre, Community and Mental Health Team, T Brugha et al, Estimating the Prevalence of Autism Spectrum Conditions in Adults: Extending the 2007 Adult Psychiatric Morbidity Survey (2012 NHS Information Centre for Health and Social Care).

51 Via <www.bailii.org> searching for 'Asperger' in the 'Court of Appeal (Criminal Division)' section of the database.

52 [2004] EWCA Crim 1834

53 [2008] EWCA Crim 6.

54 [2014] EWCA Crim 836.

55 As in the case of $\mathrm{R} v$ Piggin [2014] unreported: ' $\mathrm{T}$ t took the [police] nurse seventeen minutes to spot what everyone else had missed for seventeen years', according to Mr Ali Bajwa QC, counsel for Mr Piggin at the Old Bailey trial.

56 Janis Sharp, Saving Gary McKinnon: A Mother's Story (Biteback Publishing 2013).

57 'Free Gary McKinnon', 'CPS/Met Police will not now Try to Prosecute Gary McKinnon in the UK', posted on 14 December 2012 at 14:52<www.freegary.org.uk>.

$58 \mathrm{R} v$ Hayes [2015] EWCA Crim 1944.

59 On 26 May 2015 the prosecution opened the case to the jury.

60 L Fortado, 'UBS Trader Nicknamed Rain Man Tells Court Bosses Knew of Rigging' Financial Times (7 July 2015) <www.ft.com/content/00f0a258-2495-11e5-bd83-71cb60e8f08c>.

61 L Vaughan and G Finch, 'Rain Man Hayes with Superhero Duvet Loses Last Libor Gamble' Bloomberg Business (4 August 2015) <www.bloomberg.com/news/articles/2015-08-03/libor-dreams-end-in-prison-term-as-tomhayes-loses-last-gamble>. 
Generally, lawyers are not trained to notice indicators of ASC, though, arguably, on account of its prevalence, they should be. It is likely that some lawyers are missing the signs of possible ASC because they do not know what they are. There is no disability screening tool available to them, let alone any specific ASC screening tool for lawyers to use. The online toolkit designed specifically for advocates which gives guidance on identifying vulnerability ${ }^{62}$ has not been empirically tested and awareness of it may be poor. ${ }^{63}$

Another online source, published by the National Autistic Society, provides case studies and practical guidance to criminal justice professionals including:

A person with autism will show some of the following characteristics.

\section{Social interaction}

He or she may:

- appear to be indifferent to others or socially isolated

- be unable to read social cues

- behave in what may seem an inappropriate or odd manner

- appear to lack empathy

- avoid eye contact when under pressure.

\section{Social communication}

He or she may:

- have difficulty in understanding tone of voice, intonation or facial expression

- make a literal interpretation of figurative or metaphorical speech (for example, the phrases 'has the cat got your tongue' or 'he'd make mincemeat of you' could be alarming to a person with autism)

- find it difficult to hold a two-way conversation

- become agitated in responses or come across as argumentative or stubborn

- come across as over-compliant, agreeing to things that are not true

- use formal, stilted or pedantic language

- have poor concentration and thus poor listening skills

- be honest to the extent of bluntness or rudeness. ${ }^{64}$

... Many people with an autism spectrum disorder have difficulty processing everyday sensory information such as sounds, sights and smells ... Every individual will be affected differently, and some will be oversensitive to sensory stimulation while others will be under-sensitive and seek out sensory stimulation. People who struggle to deal with all this sensory information are likely to become stressed or anxious, and possibly feel physical pain. ${ }^{65}$

However, Maras et al noted that just $20 \%$ of solicitors and barristers [in the survey of lawyers, clients with autism and family members] indicated that steps had been taken to manage the sensory needs of a person with AS[C] in court'. ${ }^{66}$

62 Cooper (n 42).

63 Ewin (n 43).

64 National Autistic Society Northern Ireland/Department of Justice, Autism: A Guide for Criminal Justice System Professionals (National Autistic Society 2014) 7.

65 Ibid 9.

66 Maras et al (n 44). 


\section{Negligence, complaints and training}

With the increased current emphasis on the rights of those with disabilities to effectively participate in hearings, lawyers may face claims of negligence if they knew of the client's disability or ought to have known but failed to draw this to the attention of the court. However, liability would not be easy to establish; the client would have to prove, inter alia, that the lawyer's action/inaction caused an adverse outcome in the case. When the House of Lords in Hall $v$ Simons abolished barristers' immunity from negligence claims for advocacy in court there was no opening of the claims floodgates and it is likely that Lord Steyn identified the reason:

... it will not be easy to establish negligence against a barrister. The courts can be trusted to differentiate between errors of judgment and true negligence. In any event, a plaintiff who claims that poor advocacy resulted in an unfavourable outcome will face the very great obstacle of showing that a better standard of advocacy would have resulted in a more favourable outcome. ${ }^{67}$

Though the possibility of a successful professional negligence claim by a client against their lawyer for failing to identify their disability and/or draw it to the attention of the court may be remote, the possibility of a successful complaint to a professional body for the lawyer's consequent failure to uphold the proper administration of justice is less remote. This is because proving a more favourable outcome to the proceedings is not necessary for a complaint to be upheld; proving that the proceedings would have been adjusted and, for example, less traumatic for the client could be sufficient. Additionally, the lawyer may be liable under the DDA for failing to make reasonable adjustments in the supply of legal services to the client.

Lawyers' awareness of their own professional responsibilities in this regard could have a positive effect on their behaviour such that they would be more likely to incorporate disability awareness training into their professional development regime.

\section{Parties with Asperger's Syndrome and 'judgecraft' in light of Lord Justice Gillen's seven points of principle and guidance}

There was no dispute in Galo that the claimant has Asperger's Syndrome though it was largely overlooked by the parties and the Tribunal with the result that the appeal was successful and it was ordered that a freshly constituted Industrial Tribunal should hear the matter again. The Tribunal will need to heed Lord Justice Gillen's seven points of principle and guidance for procedural fairness. We consider each in turn with particular reference to the fair treatment of a party with Asperger's Syndrome.

\section{One: "It is a fundamental right of a person with a disability to enjoy a fair hearing and to have been able to participate effectively in the hearing."}

In order to comply with Article 6 of the ECHR (the right to a fair trial), judges have responsibilities to ensure that a vulnerable party can participate effectively in the hearing. In $S C v U K^{68}$ the European Court of Human Rights required that proper allowance was made for the difficulties of a young defendant to ensure effective participation in the trial process. In explaining what was meant by this, the European Court said: 
Given the sophistication of modern legal systems, many adults of normal intelligence are unable fully to comprehend all the intricacies and exchanges which occur in the courtroom: this is why the Convention, in Article 6(3)(c), emphasises the importance of the right to legal representation. However, 'effective participation' in this context presupposes that the accused has a broad understanding of the nature of the trial process and of what is at stake for him or her, including the significance of any penalty which may be imposed. It means that he or she, if necessary with the assistance of, for example, an interpreter, lawyer, social worker or friend, should be able to understand the general thrust of what is said in court. The defendant should be able to follow what is said by the prosecution witnesses and, if represented, to explain to his own lawyers his version of events, point out any statements with which he disagrees and make them aware of any facts which should be put forward in his defence. ${ }^{69}$

Ultimately, responsibility rests with the judge to ensure that the stage is set for the defendant to participate effectively. In $R v C o x^{70}$ the judge was particularly proactive. The appellant was 26 years old and had 'major difficulties which included alcohol dependency, personality disorder and a learning disability'. The extent and impact of these disabilities on his effective participation at the trial were at the heart of the appeal. The Court of Appeal concluded that the appellant had been convicted after a fair trial. Although no intermediary had been available to facilitate communication, the judge took a number of steps to give the defendant the opportunity to participate effectively. This included,

... short periods of evidence, followed by twenty minute breaks to enable the appellant to relax and his counsel to summarise the evidence for him and to take further instructions. The evidence would be adduced by means of very simply phrased questions. Witnesses would be asked to express their answers in short sentences. The tape-recordings of the interview should be played, partly to accustom the jury to the appellant's patterns of speech, and also to give the clearest possible indication of his defence to the charge. ${ }^{71}$

In Cox, the judge decided that he would have to be more interventionist than normal, maintaining close control over questioning and intervening to avoid any possible unfairness and to ensure that the appellant was not 'unduly stressed'. 72

Even if the judge does not take an 'active role', proceedings overall may be fair if what is done overall is deemed 'sufficient'. In $R v$ Dixon, ${ }^{73}$ a young defendant with Attention Deficit/Hyperactivity Disorder and a low IQ was tried with co-defendants for murder. The Court of Appeal of England and Wales said: 'We are not left with the impression that the trial judge took an active role throughout the proceedings to ensure that this vulnerable Appellant was actively participating in the proceedings. ${ }^{74}$ However, the Court of Appeal thought 'sufficient was done to enable effective participation' ${ }^{75}$ In Dixon, unlike Cox, the defendant had an intermediary throughout the trial and it may be this that the Court of Appeal thought neutralised the trial judge's lack of action.

69 Ibid [29].

70 [2012] EWCA Crim 549.

71 Ibid [21].

72 Ibid [22].

$73 \mathrm{R} v$ Dixon [2013] EWCA Crim 465.

74 Ibid [97].

75 Ibid [98]. 
When a party has Asperger's Syndrome, the steps that ought to be taken to promote their effective participation will depend on the individual concerned. As one of the leading experts in autism, Dr Lorna Wing, ${ }^{76}$ is credited with saying: "Once you have met one person with autism, you've met one person with autism." 77 This is crucial to recognise because there is wide variation in the way that autism impacts on the individual and is expressed. A judge should have no hard and fixed rules about what is required and should approach the case management task with an open mind. What was effective with one party with Asperger's Syndrome might in fact be the opposite of what is needed with another.

\section{Two: "Courts need to focus on the impact of a mental health disability in the conduct of litigation. Courts must recognise the fact that this may have influenced the claimant's ability to conduct proceedings in a rational manner.'}

The Advocate's Gateway has produced guidance in the form of a toolkit covering general principles regarding the questioning of witnesses and defendants with a mental disorder. ${ }^{78}$ The toolkit stresses that '[i]nformation about an individual's specific capabilities or condition is essential and, if not supplied, must be requested' ${ }^{79}$ In the case of a party with Asperger's Syndrome court proceedings may be the cause of considerable stress.

When one considers the inevitable difficulties people with Asperger's [S]yndrome have with regard to social reasoning, empathy, conversation skills, a different learning style and heightened sensory perception, they are clearly prone to considerable stress, anxiety, frustration and emotional exhaustion. ${ }^{80}$

Numerous studies have identified the common co-morbidities which often occur in persons with ASC, in particular, mood disorders such as depression and anxiety. ${ }^{81}$ Having a diagnosis of ASC may further exacerbate other issues in the individual's life, for instance, increasing their inability to cope and regulate their stress. ${ }^{82}$ This may be one factor which contributes to the higher mortality rate found in individuals with ASC. 83

76 C Mitchell, 'Chris Mitchell (Autism Works) Pays Tribute to Lorna Wing' (2014) <www.espa.org.uk/newsitem/chris-mitchell-autism-works-pays-tribute-to-lorna-wing >.

77 W W Murawski and K-L Scott (eds), What Really Works in Secondary Education (Corwin Press 2015).

78 L Cuthbert, Toolkit 12 General Principles when Questioning a Witness or Defendant with Mental Disorder (The Advocacy Training Council 2014). <www.theadvocatesgateway.org/images/toolkits/

12generalprincipleswhenquestionningwitnessesanddefendantswithmentaldisorder100714.pdf $>$.

79 Ibid 1

80 Attwood (n 48) 129.

81 For example: M Ghaziuddin, N Ghaziuddin and J Greden, 'Depression in Persons with Autism: Implications for Research and Clinical Care' (2002) 32(4) Journal of Autism and Developmental Disorders 299-306; R K Hammond and J M Hoffman, 'Adolescents with High-Functioning Autism: An Investigation of Comorbid Anxiety and Depression’ (2014) 7(3) Journal of Mental Health Research in Intellectual Disabilities 246-63; J L Matson and L W Williams, 'Depression and Mood Disorders among Persons with Autism Spectrum Disorders' (2014) 35(9) Research in Developmental Disabilities 2003-7.

82 C S Allely, P Wilson, H Minnis, L Thompson, E Yaksic and C Gillberg, 'Violence is Rare in Autism: When it Does Occur, is it Sometimes Extreme?’ (2017) 15(1) Journal of Psychology 49-68.

83 On mortality rates, see, for example: L Kenny, C Hattersley, B Molins, C Buckley, C Povey and E Pellicano, 'Which Terms Should be Used to Describe Autism? Perspectives from the UK Autism Community' (2015) 20(4) Autism 442-62; D E Schendel, M Overgaard, J Christensen, L Hjort, M Jørgensen, M Vestergaard and E T Parner, 'Association of Psychiatric and Neurologic Comorbidity with Mortality among Persons with Autism Spectrum Disorder in a Danish Population' (2016) 170(3) JAMA Pediatrics 243-50; T Hirvikoski, E Mittendorfer-Rutz, M Boman, H Larsson, P Lichtenstein and Bölte, 'Premature Mortality in Autism Spectrum Disorder' (2016) 208(3) British Journal of Psychiatry 232-8. 
Paquette-Smith and colleagues ${ }^{84}$ investigated suicidality in 50 adults with Asperger's Syndrome. They dichotomised their sample into those who had attempted suicide $(\mathrm{n}=18)$ and those who had not attempted suicide $(n=32)$. Findings revealed that more than 35 per cent of individuals with Asperger's Syndrome reported that they had attempted suicide in the past, a figure which is much higher than the 4.6 per cent lifetime prevalence found in the general population. Crucially, a clinical background of depression and self-reported more severe autism symptomatology were much more likely to be found in those who had attempted suicide, therefore highlighting the importance of the impact and contribution of co-morbidities in individuals with ASC and the need to recognise these co-morbidities. 85

It follows that judges and lawyers ought to be aware that a party with Asperger's Syndrome may be less tolerant of the inevitable stresses and strains of litigation and, in the most serious cases, there is a risk that they may take their own life. On the basis of the advice of a mental health professional, appropriate steps should be taken by the court to comply with its safeguarding responsibilities to protect and promote the welfare of vulnerable adults. ${ }^{86}$ This might include, for instance: adjourning the hearing so that the party may recover their mental health; excusing the party from attending the hearing but admitting their evidence in a written statement; 87 inviting the parties to submit to the Employment Tribunal in advance questions for the Employment Tribunal to put to the other party at the separate hearing; 88 supplying the cross-examination questions in advance to the person with Asperger's Syndrome so that they may answer them in writing in their own time; ${ }^{89}$ or directing that the parties collaborate to plan pre-recorded questioning of the vulnerable person by a third party. ${ }^{90}$

Three: "Courts and Tribunals can, and regularly do, have regard to the general, nonbinding guidance and practical advice of the kind given in the Equal Treatment Bench Book ... It is clear therefore that courts and tribunals should pay particular attention to the ETBB when the question of disability, including mental disability, arises.'

Gillen LJ noted in Galo that it was 'a matter of great concern that no reference appears to have been made to the ETBB by the [Industrial Tribunal]'. ${ }^{91}$ Chapter 5 of the ETBB, 'Children and Vulnerable Adults', notes that courts and tribunals are now required to 'adopt a more flexible approach'92 and sets out numerous examples.

There is limited guidance in the ETBB on Asperger's Syndrome. ${ }^{93}$ However, a toolkit - Toolkit 3 Planning to Question Someone with an Autism Spectrum Disorder including Asperger's

84 M Paquette-Smith, J Weiss and Y Lunsky, 'History of Suicide Attempts in Adults with Asperger Syndrome' (2014) 35(4) Crisis 273-7.

85 J Wilkinson, 'Supporting Individuals with Autism who Self-harm: Attributions, Emotional Response and Willingness to Help' (2015) 16(1) Good Autism Practice (GAP) 61-9.

86 Judicial College (n 26).

87 As was said should have been considered in Duffy v George [2013] EWCA Civ 908 [41] and [51]-[63].

88 Ibid [42(4)].

89 This was proposed in JW Rackham v NHS Professionals Ltd (n 26) [25] albeit rejected by the judge at first instance in that case.

90 E Isaacs, P Cooper, C Flynn, R Handa, S Little, R Marchant and S Tyler, Toolkit 13 Vulnerable Witnesses and Parties in the Family Courts (The Advocacy Training Council 2014) 30-1.

91 Galo v Bombardier Aerospace UK (n 4) [61].

92 Judicial College (n 26) 45.

93 Ibid 85-6. 
Syndrome - has been available ${ }^{94}$ since October 2013.95 That toolkit recommends, for example, that professionals questioning someone with an ASC:

... follow a logical, chronological order in questioning; use questions and explanations that are short and simply phrased, unambiguous and 'to the point'. Be clear and precise in questioning; say what you mean. Do not expect the person to understand what you are inferring/getting at. They may not know what you know or need to know, unless you say so. Check your question for alternative meanings before using it. ${ }^{96}$

In addition, The Advocate's Gateway sets out guidance on 'memory and sensory issues' in Toolkit 15 Witnesses and Defendants with Autism. ${ }^{97}$

\section{Four: "The ETBB provides helpfull information for judges about the problems experienced by [litigants with mental disabilities] in accessing the courts or tribunals or participating in proceedings ... Memory, communication skills and the individual's response to perceived aggression may all be affected ... . Expert evidence may be required". ..}

Authorities from the Court of Appeal of England and Wales establish that expert evidence should be available to the triers of facts regarding how a defendant's Asperger's Syndrome affects their presentation. Every person with Asperger's Syndrome will present in their own unique way but it is not uncommon for someone with the condition to avoid eye contact, give long detailed answers to questions that others would have answered more briefly, ${ }^{98}$ or fail to understand questions as intended (despite having a wide, comprehensive and expressive vocabulary). This might result in the misinterpretation of the presentation of a person with autism as signs of untrustworthiness, deliberate evasion of a direct question or playing for time when a tricky question is posed.

In 2014 in Thompson, ${ }^{99}$ the Court of Appeal of England and Wales found the verdicts to be unsafe because the trial jury had not known that the defendant had Asperger's Syndrome (he was not diagnosed at the time) and expert evidence 'would have been of value to the jury in determining whether, on the one hand, the appellant was evading the question or, on the other, that he was, as a result of his unusual traits, reluctant to be deflected from his pre-occupation with matters of detail'. ${ }^{100}$ Given that individuals with ASC are often impaired in their ability to appreciate the subjective experiences of others, the individual with ASC may therefore not exhibit any expression of empathy or intersubjective resonance. It is therefore important that fact-finders are aware that apparent lack of remorse or normal social functioning during courtroom proceedings is

94 '[Toolkits on The Advocate's Gateway] provide excellent practical guides and are to be commended. They have been endorsed by the Lord Chief Justice.' Vice President of the Court of Appeal (Criminal Division) in $\mathrm{R} v$ Lubemba (n 46) [40].

$95<$ www.theadvocatesgateway.org/images/toolkits/3-planning-to-question-someone-with-an-autismspectrum-disorder-including-asperger-syndrome-2016.pdf $>$

96 Ibid 3.4.2.

$97<$ www.theadvocatesgateway.org/images/toolkits/

15witnessesanddefendantswithautismmemoryandsensoryissues060315.pdf $>$.

98 As for instance occurred when the defendant was cross-examined in $R v$ Hayes ( $\mathrm{n} 58$ ).

$99 \mathrm{R} v$ Thompson (n 54).

100 Ibid [34]. 
not actually reflective of the person's actual feelings of remorse. ${ }^{101}$ This perceived lack of remorse displayed by the defendant with ASC is important to recognise as it can also be particularly detrimental to them if they are talking about their victim. In 2008 in $R v$ Sultan, ${ }^{102}$ the Court of Appeal said that if the jury had heard evidence of the defendant's Asperger's Syndrome, it 'might have gone some way to explain to the jury why the appellant was behaving so oddly at trial, such as reading a book during [the complainant's] evidence'. 103

Theory of mind (ToM) refers to a person's ability to attribute mental states (e.g. beliefs, intents, desires, pretending, knowledge) to themself and others and also the ability to understand that others have beliefs, desires, intentions and perspectives that are different from their own. ${ }^{104}$ While impairment of ToM is not a defining characteristic of Asperger's Syndrome, there is recent experimental evidence for such a deficit. ${ }^{105}$ As a result, courts should be aware that a party may act in a certain way because they fail to appreciate what others are likely to be thinking. Individuals with ASC may say things that would be considered strange.

They may also make awkward or inappropriate facial expressions. For instance, a defendant with ASC may start laughing when talking about their victim during the court proceedings. In many individuals with ASC, this outward expression may not reflect what they are actually feeling or thinking. Freckelton details the case of Brent Mack (who had a diagnosis of autism) who was charged with the murder of his mother (State of Western Australia v Mack (2012)). ${ }^{106}$ A psychiatrist who was called by the prosecution team reported that Mack had a tendency to focus on the way questions were asked rather than their content. Justice McKechnie accepted that Mack's behaviour was unusual and considered that his odd and unusual presentation may cause him 'prejudice before jurors'. For instance, he had a 'monotonous speech with an abnormal, robotic rhythm to it'. 107

The language that defendants with ASC sometimes use can very often be misinterpreted or misconstrued and can also be viewed as 'eccentric, tangential and overly formal'. 108 They may also give sudden and unexpected verbal utterances or may suddenly speak at increased volume. Individuals with ASC may also have difficulties with pragmatic communication, that is difficultly with responding in appropriate ways in social discourse. Such difficulties can be seen across a variety of areas such as: the use of gestures; personal space; timing; topic selection; and difficulties with understanding non-literal language; and also struggling to understand metaphors, irony, sarcasm or humour. Lastly, they can have unusual or odd-sounding prosody. Speaking can sound very monotonous

101 I Freckelton SC and D List, 'Asperger's Disorder, Criminal Responsibility and Criminal Culpability (2009) 16(1) Psychiatry, Psychology and Law 16-40; and P Cooper, C Berryessa and C Allely (2016) 'Understanding What the Defendant with Asperger's Syndrome Understood' (2016) 180(44) Criminal Law and Justice 792-4.

102 See above (n 53).

103 Ibid [34].

104 U Frith and F Happe, 'Autism: beyond "Theory of Mind"” (1994) 50 Cognition 115-32.

105 L Burdon and G Dickens, 'Asperger's Syndrome and Offending Behaviour' (November 2009) 12(9) Learning Disability Practice 14-20, 16, citing A Senju, V Southgate and S White et al, 'Mindblind eyes: An Absence of Spontaneous Theory of Mind in Asperger's Syndrome' (2009) 325(5942) Science 883-5.

106 I Freckelton, 'Autism Spectrum Disorder: Forensic Issues and Challenges for Mental Health Professionals and Courts' (2013) 26(5) Journal of Applied Research in Intellectual Disabilities 420-34.

107 Ibid [168].

108 Freckelton and List (n 101) 31. 
without variation in prosodic elements including speech rate and rhythm, pitch/fundamental frequency, loudness, intensity, duration and pauses/silence. ${ }^{109}$

Asperger's Syndrome does not create delusions, or amount to insanity. It does impair communication and can impair understanding of what others are thinking which may lead to misunderstanding of social signals by the person with Asperger's Syndrome and misunderstanding of their behaviour by a tribunal or court. In the case of Thompson, ${ }^{110}$ the Court of Appeal said that the trial jury:

... was very much concerned with the issue of interpretation of the appellant's alleged conduct, partly admitted and partly denied. It was to that issue that the expert evidence was primarily, although not exclusively, relevant. We cannot conclude that the decisions made by the jury in 2007 would undoubtedly have survived their consideration of the new evidence. ${ }^{111}$

The verdicts were quashed.

Five: "The presence of a McKenzie Friend in civil or family proceedings or an independent mental health advocate in a Tribunal should be encouraged in order to help locate information, prompt as necessary during the questioning of witnesses and provide the opportunity for brief discussion of issues as they arise. A more tolerant approach to the use of a lay representative may assist."

Gillen LJ's words encouraging the use of lay representatives are fully in keeping with the Lord Chief Justice's Practice Note 3/2012: McKenzie Friends (Civil and Family Courts). It applies to 'civil and family proceedings in the Court of Appeal (Civil Division), the High Court of Justice, the County Courts and the Family Proceedings Court in the Magistrates' Court. It does not apply in criminal cases.'

There is a presumption in favour of permitting a personal litigant to have reasonable assistance from a layperson, sometimes called a 'McKenzie Friend' who may provide moral support for personal litigants; take notes with the permission of the judge; help with case papers; quietly give advice on any aspect of the conduct of the case which is being heard. ${ }^{112}$

This fifth point in Galo also recognises the potential benefit of Independent Mental Health Advocates (IMHAs). The World Health Organization in 2003 stated in its publication 'Mental Health Policy and Service Guidance Package Advocacy in Mental Health' that:

Advocacy is an important means of raising awareness on mental health issues and ensuring that mental health is on the national agenda of governments. Advocacy can lead to improvements in policy, legislation and service development. ${ }^{113}$

When IMHAs are used in a court or tribunal, it is important to clarify their function and expectations of them in that particular case. Being a mental health 'advocate' is clearly not

109 J McCann and S Peppé, 'Prosody in Autism Spectrum Disorders: A Critical Review' (2003) 38(4) International Journal of Language and Communication Disorders 325-50; B G Haskins and J A Silva, 'Asperger's Disorder and Criminal Behavior: Forensic-Psychiatric Considerations' (2006) 34(3) Journal of the American Academy of Psychiatry and the Law Online 374-84.

110 See above (n 54).

111 Ibid [34].

112 Practice Note 3/2012: McKenzie Friends (Civil and Family Courts), The Right Honourable Sir Declan Morgan, Lord Chief Justice of Northern Ireland, 5 September 2012.

113 Regulation and Quality Improvement Authority, Provision of Advocacy Services in Mental Health and Learning Disability Inpatient Facilities in Northern Ireland (RQIA 2012) 5. 
the same as being an advocate in court. Is the IMHA going to be advising, supporting or both? Although not determinative, the view of the person with mental health issues is important. It is for the judge to decide and manage the role of the IMHA in court. It is noteworthy that for the Registered Intermediary pilot scheme for defendants, the mental health charity MindWise provides volunteers as supporters for vulnerable defendants in court, ${ }^{114}$ but they do not represent the defendant. Where a defendant is vulnerable on account of mental illness, a judge may order that they are accompanied during the trial by a mental health support worker from MindWise. ${ }^{115}$

\section{Six: "A modified approach may be necessary when seeking to obtain reliable evidence from a person with mental health problems especially those who are mentally frail. It is necessary to ascertain whether any communication difficulties are the result of mental impairment...'}

It has long been the case that in criminal proceedings certain witnesses (predominantly vulnerable or intimidated witnesses) are eligible for modified procedures, namely 'special measures'. Special measures are set out in the Criminal Evidence (Northern Ireland) Order 1999:

- Article 11: the witness, while giving testimony or being sworn in court, is prevented by means of a screen or other arrangements from seeing the accused;

- Article 12: the witness gives evidence by means of live link - such a direction may also provide for a specified person to accompany the witness while the witness is giving evidence by live link; ${ }^{116}$

- Article 13: evidence is given in private (by excluding people from the courtroom);

- Article 14: the wearing of wigs or gowns is dispensed with during the witness's evidence;

- Article 15: the admission of the witness's video-recorded interview as evidence in chief;

- Article 16: the admission of video-recorded cross-examination or re-examination;

- Article 17: the examination of the witness through an intermediary; and

- Article 18: the use of aids to communication.

'Vulnerable'117 witnesses are eligible for the special measures in Articles 11 to 18 (above) and 'intimidated'118 witnesses are eligible for the special measures in Articles 11 to 18 (above). ${ }^{119}$

Apart from Article 16 (pre-recorded cross-examination and re-examination), all of these special measures are now available. Pre-recording of cross-examination is a relatively small change; it moves vulnerable witnesses' evidence to before the trial and it

114 The MindWise volunteer is a supporter as distinct from a Registered Intermediary who will facilitate communication if the vulnerable defendant chooses to give evidence.

115 DOJ, Northern Ireland Registered Intermediaries Schemes Pilot Project Phase II Review (DOJ 2016$) 9$.

116 Art 12(1)A was inserted by Art 10 'Evidence by live link: presence of supporter', Justice Act (Northern Ireland) 2011.

117 Criminal Evidence (Northern Ireland) Order 1999, Art 4.

118 Ibid Art 5.

119 Ibid Art 6(1)(a). 
is recorded so that it may be played later. This can drastically reduce the stress for witnesses, who no longer have the prospect of giving evidence hanging over them for months. Under a pilot scheme at three Crown Courts in England, pre-recording of crossexamination and re-examination has been available for some vulnerable witnesses since 2013. The pilot scheme has been positively evaluated ${ }^{120}$ and pre-recording of crossexamination and re-examination will be rolled out 'from 2017'.121 This is not radical. In Australia, pre-recording of cross-examination is commonplace and has been for years in most states. ${ }^{122}$

In Northern Ireland intermediaries (Article 17) operate in criminal justice through pilot schemes. ${ }^{123}$ The most recent Registered Intermediary review report found that the Registered Intermediary role:

... continues to be essential in assisting vulnerable persons with significant communication problems during their engagement with the criminal justice process and is very well-regarded by all those who come into contact with it. As the [Registered Intermediary] Scheme is progressing well at the investigative stage and at Crown Court, it is recommended that consideration is given to formally extending the Scheme to magistrates' courts. ${ }^{124}$

There is no equivalent special measures legislation for family and civil courts in Northern Ireland. However, the family courts in England and Wales may provide a blueprint; even without special measures legislation, intermediaries have been ordered and used to support the obtaining of evidence from a person with mental frailty as this example demonstrates:

A parent in care proceedings with mental health difficulties gave evidence in a pre-recorded examination conducted by counsel in her chambers. All advocates and the judge contributed to the planning of topics to be covered and an intermediary helped counsel plan her questions. The recording of the witness's evidence was conducted by a professional third party who signed a confidentiality agreement. Questioning, including breaks, took three-and-half hours and an edited DVD lasting 90 minutes was admitted as evidence in the family proceedings. ${ }^{125}$

$120 \mathrm{~J}$ Baverstock, Process Evaluation of Pre-recorded Cross-examination Pilot (Section 28) (Ministry of Justice 2016) <www.gov.uk/government/uploads/system/uploads/attachment_data/file/553335/process-evaluationdoc.pdf $>$.

121 The equivalent provision in England and Wales, s 28 of the Youth Justice and Criminal Evidence Act 1999 , 'will be rolled out from 2017'; see the UK government response, Video Conferencing: Written Question 52289' dated 22 November 2016 <www.parliament.uk/business/publications/written-questions-answersstatements/written-questions-answers $>$.

122 S Corish, 'Issues for the Defence in Trials with Pre-recording of the Evidence of Vulnerable Witnesses' (2015) 39 Criminal Law Journal 187-97. See also P Cooper, 'A Double First in Child Sexual Assault Cases in New South Wales: Notes from the First Witness Intermediary and Pre-recorded Cross-examination Cases' (2016) 41(2) Alternative Law Journal 191-94.

123 Intermediaries were introduced in Northern Ireland in May 2013 based on the English intermediary role designed by the first author: see further P Cooper and D Wurtzel, 'Better the Second Time Around? Department of Justice Registered Intermediaries Schemes and Lessons from England and Wales’ (2014) 65(1) Northern Ireland Legal Quarterly 39-61.

124 DOJ (n 115) 13. See also DOJ, Northern Ireland Registered Intermediaries Schemes Pilot Project - Post Project Review (DOJ 2015).

125 Isaacs et al (n 90). 
In England and Wales, intermediaries have proved in some family cases to be essential to a fair hearing. ${ }^{126}$ In July 2016 the preliminary report of Northern Ireland's Review of Family and Civil Justice made numerous recommendations for family justice. It remains to be seen whether the report's recommendations - including 'pre-recording of evidential interviews, pre-court familiarisation, court supporters and special measures such as Live Link and screens' and Registered Intermediaries in the family justice system - will be implemented. ${ }^{127}$ In October 2016, recommendations for reform in the civil courts included the 'use of intermediaries ... to support those with communication difficulties in the civil and family courts'. ${ }^{128}$

\section{Seven: "An early "ground rules hearing" is indicated in the ETBB at Chapter 5. Such a hearing would involve a preliminary consideration of the procedure that the tribunal or court will adopt, taillored to the particular circumstances of the litigant.'}

The practice of ground rules hearings ${ }^{129}$ was introduced through Registered Intermediaries in England and Wales: 'Many judges and advocates find [ground rules hearings] "invaluable"; they provide a mechanism by which the judge can set the parameters for the fair treatment of vulnerable witnesses and defendants. ${ }^{130}$ In Dixon, ' $[\mathrm{t}]$ he absence of a ground rules hearing prior to trial with the judge did not make the trial unfair, although failure to take this step was regrettable'.131 However, this decision predates the case of Lubemba ${ }^{132}$ when the Court of Appeal decision determined that a ground rules hearing should take place when a case involves a vulnerable person unless the circumstances are very exceptional.

Gillen LJ set out examples of what might be considered at a ground rules hearing.

- The approach to questioning of the claimant and to the method of crossexamination by him/her. Adaptations to questioning may be necessary to facilitate the evidence of a vulnerable person.

- How questioning is to be controlled by the Tribunal.

- The manner, tenor, tone, language and duration of questioning appropriate to the witness's problems.

- Whether it is necessary for the Tribunal to obtain an expert report to identify what steps are required in order to ensure a fair procedure tailored to the needs of the particular applicant.

- The applicant under a disability, if a personal litigant, must have the procedures of the court fully explained to him and advised as to the availability of pro bono assistance/McKenzie Friends/voluntary sector help available.

126 P Cooper, 'Like Ducks to Water? Intermediaries for Vulnerable Witnesses and Parties' (2016) 46(3) Family Law 374-8.

127 The Right Honourable Lord Justice Gillen/The Review Group, Review of Civil and Family Justice: The Review Group's Draft Report on Family Justice (Judicial Studies Board 2016) ch 12, 'The Voice of the Child and Vulnerable Adults'.

128 Ibid 203.

129 The ground rules approach was devised by the first author in Registered Intermediary training and researched through the first author's Registered Intermediary surveys in England and Wales.

130 P Cooper, P Backen and R Marchant, 'Getting to Grips with Ground Rules Hearings: A Checklist for Judges, Advocates and Intermediaries to Promote the Fair Treatment of Vulnerable People' (2015) 6 Court Criminal Law Review 417-32, 417.

$131 \mathrm{R} v$ Dixon (n 73) [95].

$132 \mathrm{R} v$ Lubemba (n 46) [42]. 
- Recognition must be given to the possibility that those with learning disabilities need extra time even if represented to ensure that matters are carefully understood by them.

- Great care should be taken with the language and vocabulary that is utilised to ensure that the directions given at the ground rules hearing are being fully understood.

- As happened in the Rackham case [J W Rackham v NHS Professionals Ltd $\left.{ }^{133}\right]$, consideration should be given to the need for respondent's counsel to offer cross-examination and questions in writing to assist the claimant with the claimant being allowed some time to consult, if represented, with his counsel. These were deemed "reasonable adjustments".

- The Tribunal must keep these adjustments needed under review. ${ }^{134}$

Gilllen LJ stressed the need for an 'early' ground rules hearing. In England and Wales the Criminal Practice Directions recommend that: 'Discussion before the day of trial is preferable to give advocates time to adapt their questions to the witness's needs.' ${ }^{135}$ However, since the ground rules Gillen LJ has in mind are about much more than questioning, they would need to be set as early as possible in the proceedings so that interim hearings for case management, the communication between the court and the party, disclosure procedure, orders in relation to obtaining expert evidence and support for the party, and so on, are all adjusted where appropriate. If the case proceeds to a final hearing, at that stage there would need to be a further ground rules hearing with a specific focus on the questioning of the party with a disability. 136

In England and Wales, recent Court of Appeal decisions have established that planning to question a vulnerable person is a collaborative exercise involving all the advocates, the judge and the intermediary (if there is one in the case). In 2014 the Court of Appeal in Lubemba endorsed the practice of judges inviting advocates to provide their questions in writing in advance so that they may be vetted by the judge, as well as by the intermediary if there is one. ${ }^{137}$

In 2015 the Court of Appeal twice endorsed a collaborative approach to the planning of questions for a vulnerable witness. In $\mathrm{R} v \mathrm{~F} A,{ }^{138}$ when setting ground rules prior to taking fresh evidence from a vulnerable witness, the Court of Appeal required the defence to share their proposed questions with the intermediary so that they might provide useful assistance. In $R v R L,{ }^{139}$ in advance of the ground rules hearing, counsel provided a list of the questions which he proposed to ask two boys. The judge considered the questions and the 'intermediary was able to assist the court in relation to both boys on questions such as whether they would have difficulty understanding questions asked in particular terms'.140

133 See above (n 26).

134 Galo v Bombardier Aerospace UK (n 4) [53(7)].

135 CPD 2015, s 3E.3.

136 As to the use of intermediaries, 'suggested universal ground rules' for questioning and $\mathrm{R} v$ Rasbid [2017] EWCA Crim 2, see P Cooper, 'Moving the Bar: Is Cross-examination any Good?' (2017) (March) 74 Mental Capacity Report: Practice and Procedure 3-6. <www.39essex.com/content/wp-content/ uploads/2017/03/Mental-Capacity-Report-March-2017-Practice-and-Procedure.pdf $>$.

$137 \mathrm{R} v$ Lubemba (n 46) [43].

$138 \mathrm{R} v \mathrm{FA}$ [2015] EWCA Crim 209.

$139 \mathrm{R} v \mathrm{RL}$ [2015] EWCA Crim 1215.

140 Ibid [6]. 
The ground rules approach, including advocates collaboratively planning the questions with the assistance of the intermediary where there is one, is good practice and works even in the adversarial system because the intermediary is neutral and impartial. It is suggested that, even if there is no intermediary, advocates should write out their questions in order more easily to check that they are expressed in a way that is suitable for the vulnerable witness.

However, even when an intermediary is available, communication between the crossexaminer and the defendant with Asperger's Syndrome may not be fully coherent as this specimen extract form $R v$ Hayes demonstrates. ' $Q$ ' is the prosecutor's question and ' $\mathrm{A}$ ' is Mr Hayes' answer. ${ }^{141}$

Q. Prosecution counsel is referring to the transcripts of telephones calls made at the bank.] You say: 'Just give the cash desk a Mars Bar and they'll set whatever you want. They're usually staffed by fat people.' He says: 'Hahaha, brilliant.' Now, you were - well, were you - was that a joke?

A. Which part?

Q. The bit about the cash desk with the Mars Bar?

A. I never gave the cash desk a Mars Bar.

Q. I'm not asking you that. I'm asking you was it a joke?

A. Yes.

Q. But - all right. If you misunderstand my question, you must say so. Although it was a joke; yes?

A. Yes. The bit at the end was a joke.

A vulnerable witness or defendant with ASC cannot always know when he misunderstands the question, instead he may interpret it in a different way, not realising that the questioner intended a different meaning. In these circumstances, it is the responsibility of the judge, with assistance from counsel and the intermediary, to intervene when a question is ambiguous or when the answers indicates misunderstanding. Ultimately, the judge must take all reasonable steps to ensure the witness is questioned in a way that he or she can understand, particularly when being challenged. In 1894 in the House of Lords, Lord Herschell LC said in Browne v Dunn (1894) 6 R 67:

My Lords, I have always understood that if you intended to impeach a witness you are bound, whilst he is in the box, to give him an opportunity of making any explanation which is open to him; and, as it seems to me, that is not only a rule of professional practice in the conduct of a case, but is essential to fair play and fair dealing with witnesses. [71]

Echoing this in 2015, Lord Hughes in Director of Public Prosecutions v Nelson (Antigua and Barbuda) said: 'The gravamen of it is fairness. The witness, and in particular a defendant witness, must not be deprived of the opportunity to deal with a particular suggestion by its being unspoken when it ought to be put directly.142

The court or tribunal may wish to go one step further as was proposed in $J$ Rackham $v$ NHS Professionals Ltd (as cited in Galo): the claimant with Asperger's Syndrome could be supplied with the questions in writing in advance so that he should take the questions away and answer them in writing in his own time'. ${ }^{143}$

141 From the Merrill Corporation official transcript, Day 29, 8 July 2015, pages 20-22.

142 Director of Public Prosecutions v Nelson (Antigua and Barbuda) [2015] UKPC 7 [24].

143 J W Rackham v NHS Professionals Ltd (n 26) [25]. 
In Northern Ireland the Registered Intermediaries Schemes Review of 2016 'considered that it would be helpful to formally provide for [ground rules hearings] in the statutory case management Regulations'. ${ }^{144}$ However, such regulations if introduced would apply only in criminal cases. Ground rules hearings in other cases would be a matter for the judge under their general, inherent case management powers and responsibilities.

\section{In conclusion}

In 2013 the Supreme Court said:

There is no doubt that one of the virtues of procedurally fair decision making is that it is liable to result in better decisions, by ensuring that the decision maker receives all relevant information and that it is properly tested . . J Justice is intuitively understood to require a procedure which pays due respect to persons whose rights are significantly affected by decisions taken in the exercise of administrative or judicial functions. Respect entails that such persons ought to be able to participate in the procedure by which the decision is made, provided they have something to say which is relevant to the decision to be taken. ${ }^{145}$

Judges and lawyers alike are charged with the responsibility of upholding the proper administration of justice, including ensuring adjustments are in place to guarantee the fair treatment and questioning of those with disabilities. Lawyers may be found to be professionally negligent, to have breached their code of professional conduct and to have fallen foul of the DDA if they do not alert the court to their client's disability. This requires lawyers not only to respond to a client's disclosure of disability but to actively look out for indicators and refer the client for a diagnostic assessment where appropriate. Awareness is key, but it is also a major challenge:

In responding to these difficulties [in identification of vulnerable and intimidated witnesses], the most significant challenge for the criminal justice system is to make staff aware of the range of vulnerabilities and to equip them with sufficient understanding to recognise when more expert help and assistance needs to be provided. ${ }^{146}$

Even if awareness is achieved, there is another possibly even greater challenge; changing behaviour towards those with a disability who are caught up within the adversarial model of fact-finding:

A commitment to reform is hampered as much by a misconceived fidelity to the conventional way of doing things and a reluctance to overly disturb familiar and reified patterns as it is by concerns over the potential for injustice for accused parties. ${ }^{147}$

In Galo, the Lord Justice Gillen's seven points for procedural fairness set a framework for behavioural change at hearings. Lawyers must accept that best practice now dictates a collaborative approach to planning questions; this may seem alien at first in an adversarial system. That judges are already becoming more interventionist for reasons of efficiency

144 DOJ (n 115).

145 Osborn v The Parole Board [2013] UKSC 61 [67]-[68].

146 Criminal Justice Inspection Northern Ireland, The Use of Special Measures in the Criminal Justice System in Northern Ireland (CJINI 2012) vii.

147 S Kilcommins, S Edwards and T O’Sullivan, An International Review of Legal Provisions and Supports for People with Disabilities as Victims of Crime (Irish Council for Civil Liberties 2013). 
has been noted. ${ }^{148}$ However, quite apart from efficiency, judges must take an active role and intervene if necessary to uphold the fundamental right of people to access to justice. Experience tells us that judges can and do regularly intervene in cross-examination in any event in order to clarify evidence for the benefit of the jury ${ }^{149}$ or for themselves, but, in the case of a person with a disability affecting communication, this intervention must be nuanced and focused on the needs of the person. The practice of judges 'vetting' questions, requiring advocates to draft them in advance and consult with an expert communication advisor such as an intermediary, or even provide the witness with the questions in advance, may well take judges out of their judgecraft comfort zone. So too, perhaps, might the presumption in favour of the active presence of a lay representative or supporter for a vulnerable party.

There are many sources of advice available to judges and advocates in the form of online guidance, most notably the ETBB and The Advocate's Gateway. However, knowledge is only as good as its application in practice. Training will be key. Lord Justice Gillen's judgment may prove to be a watershed. There is far more at stake than efficient case management. Access to justice and the legitimacy of the justice system are at risk. The opposite of procedural fairness in court is procedural discrimination in court.

Discrimination is an insidious practice. Discriminatory law undermines the rule of law because it is the antithesis of fairness. It brings the law into disrepute. It breeds resentment. It fosters an inequality of outlook which is demeaning alike to those unfairly benefited and those unfairly prejudiced. ${ }^{150}$

148 E Johnston, 'All Rise for the Interventionist: The Judiciary in the 21st Century' (2016) 80(3) Journal of Criminal Law 201-13.

149 See, for example, $R v$ Adams [2015] NICA 24.

150 Ghaidan v Godin-Mendoza [2004] UKHL 30, [9]. 